\title{
Development of Student Awareness through Student Learning Model Jurisprudential in Citizenship Education
}

\author{
T Heru Nurgiansah and Suwarma Al Muchtar \\ Sekolah Pascasarjana \\ Universitas Pendidikan Indonesia \\ Bandung, Indonesia \\ therunurgiansah@gmail.com
}

\begin{abstract}
Education should be able to provide experience and experience to improve the quality of learning for the achievement of National Education. Improving the quality of education is very important to produce students into a generation of smart and skilled in dealing with challenges in a changing global life. The purpose of this study is to find out how the development of legal awareness of student traffic through jurisprudential learning model in Civic Education. This research uses qualitative approach with descriptive method and the data obtained through observation technique, interview, and documentation. Subjects in this study were students, teachers and the police. Data analysis techniques used consisted of three activities that occur simultaneously that is data reduction, data presentation and conclusion. The results showed that the utilization of a jurisprudential learning model as the implementation of Civic Education learning can have a positive impact on teachers in identifying the needs and obstacles of students in learning. In addition, it can improve the quality of learning on the level of legal awareness of student traffic as young citizens. Therefore the development of Citizenship education as a vehicle for legal awareness education should continue and required steps that are carried out continuously and comprehensively.
\end{abstract}

Keywords—civic education; jurisprudential learning model; legal awareness

\section{INTRODUCTION}

Economic growth and large population because the fulfillment activity of transportation means to increase, so that will cause the growth of motor vehicle ownership in Indonesia from year to year have significant increase [1]. The increase of motor vehicle ownership is not accompanied by supporting facilities and infrastructure such as road widening will cause a number of problems such as congestion which is a crucial problem that often occurs in the streets of protocol in Indonesia [2]. Problems other than traffic jams are the high number of traffic accidents caused by inadequate roads such as potholes and lack of lighting at night, as well as non-legal driving behavior by driving without having a driver's license and other driving fittings [3]. The main problem in traffic is traffic accidents most involving a motorcycle driven by student [4].
Traffic violations can be caused by a number of possibilities, either due to a lack of legal awareness of road users, as well as the completeness of the vehicle itself [5]. Future traffic problems, especially traffic accidents, will continue to increase if public legal awareness of the importance of orderly ethics has not been fully realized [6]. The low awareness of student law on traffic regulations is evident from the high traffic violations. Based on preliminary observations conducted by researchers, found various kinds of violations committed by students of Vocational High School Bina Essa West Bandung regency, such as not using a helmet, not turning on the headlight during the day, using noisy exhaust, not equipped with vehicle registration and driver license. Whereas POLRI has full authority related to the issuance of SIM, STNKB, STCKB, and TCKB [7]. Other violations are commonly done by students who rode more than two people. This happens because of the lack of students' understanding of the prevailing traffic rules which resulted in the low awareness of the law of the students and the habit of society [8].

Based on pre-research data that has been done at Police Resort Cimahi, obtained data that the number of violations the most traffic done by students is the completeness of the vehicle reaches 6,961 offenders. Completeness of vehicles include rearview mirror, lights, and motor vehicle number (TNKB). The second highest number of offenses is not using a helmet that reaches 5,524 offenders. The third largest number of violations is no driver's license (SIM) which reached 2,590 violators. Then breaking traffic signs reaching 143 offenders, such as breaking through red lights, parking and stopping haphazardly, using the sidewalk to avoid congestion. Other violations reached 389 offenders such as riding more than two people, using noisy exhaust, not turning on the light during the day and not using seat belts for four-wheeled vehicles (Head of Traffic Unit of Cimahi Police, 2017).

The incident cannot be left alone because it will result in the emergence of chaos that can disrupt the order and comfort of driving. It is appropriate school and the police play an active role in dealing with this problem, especially awaken the behavior of students in driving in order to create safe traffic, orderly, organized and comfortable. One of the duties of the police is to socialize the regulation of the use of two-wheeled 
vehicles that is good, safe and does not cause harm to others and the provision of sanctions information if there are violations in the use of two-wheeled vehicles [8]. It does not attempt only the police who had to aggressively address this issue, but the school else has the responsibility and obligation to provide knowledge to students obey traffic regulations. School is an educational institution that is tasked to form the character and personality of students. The subject of Civic Education is one of the subjects in school are most appropriate to establish the legal awareness of students as subjects of a shutter as legal education for students [9].

The awareness of the law of traffic is very interesting to be studied in Citizenship Education, the interesting factors can be seen from the students' compliance in traffic, the discipline of students in obeying traffic signs and tolerance in driving the highway with fellow users of vehicles and pedestrians [10]. The figure of teachers in guiding and monitoring the development of student attitudes is a figure that is not less important, beside role of the school and police forces, as well as the role of Civic Education. Unattended, teachers will not know how their students behave when coming or coming home from school. Schools also do socialization to parents about the importance of instilling well-mannered behavior during traffic. Another important addition to the supervision of teachers is a professional teacher that is teachers who are able to use various media and methods or learning models in teaching and learning activities.

This research will find the development of legal awareness of student traffic through jurisprudential learning model in Citizenship Education there students Class $\mathrm{X}$ of Office Administration in SMK Bina Essa Regency of West Bandung. The subject of Citizenship Education is a subject that focuses on the establishment of citizens who are able to understand and exercise their rights and obligations to be intelligent, skilled and characterized Indonesian citizens [11]. Jurisprudential teaching model in Citizenship Education there students Class X of Office Administration in SMK Bina Essa Regency of West Bandung is a suitable learning model for developing students' legal awareness of the law. This learning model is able to develop legal awareness of students' traffic while changing the habits of teachers who teach conventionally without developing the creativity of their students.

\section{RESEARCH METHODS}

This research uses qualitative approach with descriptive method because of reality and events that take place in the field that researchers can focus attention on natural events that occur and experienced students in the use of motor vehicles. This research was conducted in SMK Bina Essa, West Bandung regency. Informant of this research is student of SMK Bina Essa West Bandung Regency, Civic Education Teacher and Police Resort Cimahi represented by Head of Traffic Unit (Kasat Lantas) Police Cimahi. During the first study was observation, followed by interview and documentation with informants. The results of data collection obtained are then analyzed using Miles and Huberman models.

\section{RESULTS}

Results of research conducted by investigators at the time of observation, students are less like a lecture in Civic Education learning because it feels very boring. Half of the students in class state that never had a study group but did not long survive. Results of research on the application of jurisprudential learning model in study of Civic Education in class X of Office Administration in SMK Bina Essa West Bandung regency showed that half of the students of class $\mathrm{X}$ still looks hesitant and shy when expressing their opinions. In the opinion of one of the students of class $\mathrm{X}$ of Office Administration in SMK Bina Essa West Bandung regency jurisprudential learning model can make them more sensitive to the social problems that occur in the vicinity, they can understand in depth the material being learned and can apply it in everyday life, especially in obeying traffic regulations. Although at the beginning of the learning process was still very hesitant, but the quality of the display shown very interesting. Opinion of one teacher in class X of Office Administration in SMK Bina Essa West Bandung regency that the material presented is effective in increasing the activity of students in learning. Jurisprudential learning model application in the classroom shows that teachers no longer speak but student center. Although at the beginning of the learning process was still very hesitant, but the quality of the display shown very interesting. Opinion of one teacher in class $\mathrm{X}$ of Office Administration in SMK Bina Essa West Bandung regency that the material presented is effective in increasing the activity of students in learning. Jurisprudential learning model application in the classroom shows that teachers no longer speak but student center. Although at the beginning of the learning process was still very hesitant, but the quality of the display shown very interesting. Opinion of one teacher in class X of Office Administration in SMK Bina Essa West Bandung regency that the material presented is effective in increasing the activity of students in learning. Jurisprudential learning model application in the classroom shows that teachers no longer speak but student center.

The results of the study at SMK Bina Essa West Bandung regency obtained that planning done in the application of the model jurisprudential learning Citizenship Education to raise the legal awareness of traffic class $\mathrm{X}$ of Office Administration in SMK Bina Essa West Bandung District is conducting a learning strategy with a variety of case material through observation, discussion, question-answer, presentation and manufacturing tasks. It proves the change marked by increasing knowledge and understanding of students' legal values in road traffic, as well as the increasingly visible also patterns of behavior and attitude of students is the student's ability in giving opportunity to others in the group to equally enjoy the rights and the same obligations, students mutual respect and a positive outlook on other members and sensitive to others. Provide an opportunity for friends to take turns when asking questions when discussing in groups and when present the results of the discussion in the classroom.

Jurisprudential learning model in Citizenship Education in class X of Office Administration in SMK Bina Essa West Bandung regency seems to have managed to raise awareness of road traffic law students. Such improvements can be seen from 
the attitude and students' understanding of the material a traffic violation cases during the learning materials such as knowledge of traffic laws: students know certain behaviors are regulated by law. Understanding of the law: the students have the knowledge and understanding of certain rules set by the law. The attitude of the law: the students have a tendency to conduct an assessment of the legal rules. Legal behavior: students behave in accordance with applicable laws or in the sense that the students already have knowledge and understanding that an act governed by law, attitude in the sense that students have been able to provide an assessment of applicable law, and behavior in the sense that students can already behave in accordance with applicable law, whether in the life of family, school and community.

Learning model application jurisprudential on the subjects of civic education to sensitize law-traffic student is (a) to plan the learning process in the classroom and try to establish an atmosphere of active class with ways to motivate students by providing additional value or points to students who ask or express their opinions, (b) provide additional tasks that can enhance students' learning activities that improve student achievement, instilling discussion in every lesson, (c) selecting and writing topics of interest and to motivate students to be actively involved in the learning Citizenship Education, then bring up a discourse which raises critical questions,(D) the teacher tried to apply various methods of learning in each lesson, Hali is to make students more comfortable in learning and being bored, (e) discusses social problems that are hot happening outside the school environment, especially concerning violations of the traffic through the media television, radio or print media, and then associated with the material to be covered by an attractive learning strategies such as discussion and debate. Then associated with the material to be covered by an attractive learning strategies such as discussion and debate. Then associated with the material to be covered by an attractive learning strategies such as discussion and debate.

Constraints on the implementation of learning that are often faced by teachers in teaching civic education with a model jurisprudential to raise legal awareness of traffic class $X$ of Office Administration in SMK Bina Essa West Bandung regency is the allocation of time learning Citizenship Education relatively short compared with the extent of the material being studied, the lack of creativity of teachers and reference source provider of books that are relevant to civic education materials and facilities and infrastructure in schools which lack support in the learning process. In addition, students are still not familiar with the model of learning by questioning techniques, students are still shy to ask questions, as well as the difficulty in building an atmosphere of active class and democratic, students are also unfamiliar with tasks performed outside the classroom.

\section{DISCUSSION}

Legal awareness of traffic of students needs to be fostered through coaching, discipline students in the learning process that focuses on the legal values and norms of traffic and habituation to always obey and adhere to the rules that apply in school and in order on the highway with the provision the right example by teachers as role models in the school. It is shown that the students were able to stand on its own and create a fun atmosphere of learning so that they comply with all applicable regulations. One of the efforts that need to be done by the Citizenship Education teachers so that learning is not only emphasizes the cognitive aspects, it should be able to choose the appropriate methods of learning and teaching model that is considered supportive learning Citizenship Education. Research that concerning the Development of Integration of Education Traffic In Subjects Civics Through Media WebBased Learning To Improve Legal Awareness of Students SMPN 5 Bandung is one study that aims to improve legal awareness through the medium of web-based learning. This research resulted in that the web-based learning media contribute to increased awareness of road traffic law students in the learning materials integration of traffic education in the subjects of civics.

In contrast to the model of learning in previous studies using web-based learning media, this study used a learning model jurisprudential in Citizenship Education has managed to raise awareness of traffic laws class $\mathrm{X}$ of Office Administration in SMK Bina Essa West Bandung regency. Jurisprudence learning model aims to train the ability to process information and resolve social issues with terms of reference or jurisprudential thinking (the science of human laws), class $\mathrm{X}$ of Office Administration in SMK Bina Essa West Bandung regency required to analyze or identify public policies to relieve or issue traffic violations to relate to them and the underlying values [12]. The learning model jurisprudential is a method that challenges students to learn to find a solution to a problem or policy issues and conflicts, the issue is used to associate a sense of curiosity, analytical skills of students and student initiative on the subject matter and to train students to be sensitive to social issues, took the position (attitude) to these problems. This model can also teach students to be able to accept or appreciate other people's attitudes to a problem that may conflict with that attitude in him [13]. The analytical skills of students and student initiatives on the subject matter and to train students to be sensitive to social problems, took the position (attitude) to these problems. This model can also teach students to be able to accept or appreciate other people's attitudes to a problem that may conflict with that attitude in him [13]. The analytical skills of students and student initiatives on the subject matter and to train students to be sensitive to social problems, took the position (attitude) to these problems. This model can also teach students to be able to accept or appreciate other people's attitudes to a problem that may conflict with that attitude in him [13].

Citizenship education is one of the subjects in the most appropriate schools to build awareness of students as subjects of law is a means of legal education for students. Citizenship education as continuing legal education, which means that this educational program geared to fostering students as citizens who have high legal awareness, aware of their rights and obligations and have a high compliance with the law [9]. Citizenship education has considerable influence in the socialization of law in formal education starting from primary level, secondary to tertiary education. The role and function of Civic Education in relation to shaping legal awareness of 
students is to create and nurture a student's life in the public order. This is done by the students in a way to obey all the rules of law in our country. Each student is a part of such citizens are required to have law awareness so that people's lives orderly, safe and peaceful [14].

Based on the results of learning Citizenship Education using jurisprudential method can increase legal awareness for students can be seen from the attitude of the student's behavior in the use of motor vehicles. In formal education Civic education can be a means of socialization laws set by the state, students who incidentally is the next generation are expected to understand the laws that apply in Indonesia. Citizenship Education subject is a subject that focuses on the formation of citizens who are able to understand and carry out their rights and obligations to become Indonesian citizens who are intelligent, skilled and character [11]. Legal awareness of traffic being taught in class $\mathrm{X}$ of Office Administration in SMK Bina Essa West Bandung regency by the school through civic education learning model jurisprudential greatly improve the understanding and behavior of adherence to the rules, this is because the school is an educational institution whose job is to shaping the character and personality of students. Schools serves to educate and train and foster budding young generation of the nation so as to create a condition that is safe, orderly, organized, disciplined and responsible. With their learning in school is expected to shape the attitudes and behavior of students become good citizens [11].

Jurisprudential learning model teaches students to teach learners to analyze and think systematically and critically in response to the warm central issue in the community. That is, the model is to teach learners in terms of critical thinking on social issues [15]. One key objective of schooling is enhancing students' abilities to think critically, to the make rational decisions about what to believe [16]. The main purpose of education is to improve the capability of students to think critically in order to intelligently make a rational decision about what to believe. Jurisprudential learning strategies using a variety of processes in answering questions and solving problems based on the logical test on the basis of facts and observations to teach content and help students to think analytically. Jurisprudential learning starts with giving students the issues related to the content that will be the focus for the activities of classroom study. In an attempt to solve the problem, learners generate hypotheses or solutions to these problems, collect data considered relevant to the hypotheses that have been made, and evaluate the data to arrive at a conclusion [17]. Through jurisprudential model of learning, learners learn content related to the problem in question as well a variety of strategies to solve problems in the future. Implementation of the learning model is more suitable jurisprudential operationalized to learners who have a high school or vocational development of the power of reason is considered better than the age of the child underneath. Implementation of jurisprudential learning model should be applied to the relevant materials as well as actual, or cases that are still being warm place. Learners learn content related to the problem in question as well a variety of strategies to solve problems in the future. Implementation of the learning model is more suitable jurisprudential operationalized to learners who have a high school or vocational development of the power of reason is considered better than the age of the child underneath. Implementation of jurisprudential learning model should be applied to the relevant materials as well as actual, or cases that are still being warm place. Learners learn content related to the problem in question as well a variety of strategies to solve problems in the future. Implementation of the learning model is more suitable jurisprudential operationalized to learners who have a high school or vocational development of the power of reason is considered better than the age of the child underneath. Implementation of jurisprudential learning model should be applied to the relevant materials as well as actual, or cases that are still being warm place.

\section{CONCLUSION}

Efforts to raise the legal awareness of traffic class $\mathrm{X}$ of Office Administration in SMK Bina Essa West Bandung regency through models jurisprudential in Citizenship Education has been apparent increases, it can be seen from: a) Learning Citizenship Education held in the classroom not only focuses on the mastery of the material cognitive learning, but students are also given an active role to find their own range of issues related to the expected learning experience; b) Citizenship Education Learning has been done with the learning method that is not indoctrinate, thus encouraging the strengthening of the role and position of Civic Education as legal awareness education for students.

Learning to use a worksheet or the student experience by associating events occurring cases or issues in people's lives by using the steps jurisprudential models can guide the students to be active in improving their skills and awareness of road traffic law students. Guidance and motivation given by the teacher to add interest will challenge students to think that the learning process will be more interesting. Event searching for, identifying cases, selecting cases, test cases of traffic violations and to enhance the knowledge, understanding, attitudes and behaviors of traffic law students.

Legal awareness is a reflection of the knowledge, understanding, attitudes and behavior of each student to the rights and obligations both as individuals and groups can be internalized through Civic Education. This can be realized if the student's learning process Civics equipped with the knowledge to become good citizens, and trained to create atmosphere lives of Indonesian citizens and legal political literacy.

\section{REFERENCES}

[1] D. Dedi, Strategi Satuan Polisi Lalu Lintas Resort Pontianak Kota Dalam Mengurangi Kecelakaan Lalu Lintas di Kota Pontianak, Pontianak: Universitas Tanjungpura, 2013.

[2] J. Jukangko and H. Harmanto, Peran Radio Suara Surabaya Sebagai Media Pendidikan Untuk Tertib Berlalu Lintas Bagi Warga Kôta Surabaya, Surabaya: PPKn FIS UNESA, 2013.

[3] M. Junef, "Perilaku Masyarakat Terhadap Operasi Bukti Pelanggaran (TILANG) Dalam Berlalu Lintas,” E-Journal Widya Yustisia, 2014.

[4] H. Hendrati and H. Hidayati, Analisis Risiko Kecelakaan Lalu Lintas Berdasar Pengetahuan, Penggunaan Jalur, dan Kecepatan Berkendara, Surabaya: Universitas Airlangga, 2016. 
[5] R.D. Ramasari, Efektivitas Pelaksanaan Undang-Undang Nomor 22 Tahun 2009 Tentang Lalu Lintas dan Angkutan Jalan Dalam Menekan Tingkat Kecelakaan Lalu Lintas, Universitas Bandar Lampung, 2010.

[6] A.R. Anita, Upaya Kepolisian Dalam Memberikan Perlindungan Bagi Korban Tabrak Lari. Universitas Atmajaya Yogyakarta, 2015.

[7] P.Y. Riswanty, Batas Kewenangan Penyidik Pegawai Negeri Sipil dan Kepolisian Dalam Penindakan Pelanggaran lalu Lintas dan Angkutan Jalan. Bali: Universitas Udayana, 2004.

[8] S. Sadono, Budaya Tertib Berlalu Lintas "Kajian Fenomenologis Atas Masyarakat Pengendara Sepeda Motor di Kota Bandung". Yogyakarta: Universitas Ahmad Dahlan, 2016.

[9] M. Maftuh and S. Sapriya, "Pembelajaran PKn Melalui Konsep," Jurnal Civicus Implementasi KBK dalam Berbagai Konteks, 2005, pp 319-328.

[10] P. Prayogi, Z. Zahirman and H. Hambali, Studi Tentang Kesadaran Hukum Berlalu Lintas Menurut UU No 22 Tahun 2009 Pada Siswa SMA Negeri 1 Rambah Kecamatan Rambah Kabupaten Rokan Hulu. Universitas Riau, 2013.
[11] N.D. Cahyani, Peranan Guru Pendidikan Kewarganegaraan Dalam Meningkatkan Kesadaran Hukum Berlalu Lintas Pada Siswa SMP N Mirit Kabupaten Kebumen. Universitas Negeri Yogyakarta, 2013.

[12] B. Joyce, M. Weil and E. Calhoun, Models Of Teaching : Model-Model Pengajaran. Upper Saddley River, New Jersey, USA. Edisi Bahasa Indonesia. Yogyakarta: Pustaka Pelajar, 2009.

[13] H.B. Uno, Model Pembelajaran: Menciptakan Proses Belajar Mengajar yang Kreatif dan efektif. Jakarta: PT Bumi Aksar, 2007.

[14] S. Wuryan, Ilmu Kewarganegaraan (CIVICS). Bandung: Laboratorium Pendidikan Kewarganegaraan Universitas Pendidikan Indonesia, 2008.

[15] M. Wena, Strategi Pembe-lajaran Inovatif Kontemporer. Jakarta: Bumi Aksara, 2010

[16] R.E. Slavin, Educational Psychology: Theory and Practice. Boston: Pearson Education, Inc. 1994.

[17] A. Allyn and B. Bacon, Methods for Teaching. New Jersey: Pearson Education, 2009. 